\title{
Post-Golgi Trafficking and Transport of Cell Wall Components
}

\author{
Rosalie Sinclair*, Michel Ruiz Rosquete and Georgia Drakakaki* \\ Department of Plant Sciences, University of California, Davis, Davis, CA, United States
}

The cell wall, a complex macromolecular composite structure surrounding and protecting plant cells, is essential for development, signal transduction, and disease resistance. This structure is also integral to cell expansion, as its tensile resistance is the primary balancing mechanism against internal turgor pressure. Throughout these processes, the biosynthesis, transport, deposition, and assembly of cell wall polymers are tightly regulated. The plant endomembrane system facilitates transport of polysaccharides, polysaccharide biosynthetic and modifying enzymes and glycoproteins through vesicle trafficking pathways. Although a number of enzymes involved in cell wall biosynthesis have been identified, comparatively little is known about the transport of

OPEN ACCESS

Edited by: Diane C. Bassham, lowa State University, United States

Reviewed by: Harriet T. Parsons, University of Copenhagen, Denmark Gian Pietro Di Sansebastiano, University of Salento, Italy

*Correspondence: Rosalie Sinclair rmsinclair@ucdavis.edu

Georgia Drakakaki gdrakakaki@ucdavis.edu

Specialty section: This article was submitted to Plant Cell Biology,

a section of the journal Frontiers in Plant Science

Received: 02 July 2018 Accepted: 16 November 2018 Published: 07 December 2018

Citation:

Sinclair $R$, Rosquete MR and Drakakaki G (2018) Post-Golgi Trafficking and Transport of Cell Wall

Components.

Front. Plant Sci. 9:1784. doi: 10.3389/fpls.2018.01784 cell wall polysaccharides and glycoproteins by the endomembrane system. This review summarizes our current understanding of trafficking of cell wall components during cell growth and cell division. Emerging technologies, such as vesicle glycomics, are also discussed as promising avenues to gain insights into the trafficking of structural polysaccharides to the apoplast.

Keywords: post-Golgi trafficking, trans-Golgi Network, endosome, polysaccharide trafficking, cell wall, endomembrane trafficking, glycome analysis, SNARE

\section{THE PLANT CELL WALL}

Consisting of a complex weaving of macromolecules, the cell wall is essential for many cellular processes such as development, cell integrity, signal transduction, defense, and maintenance of turgor pressure (Collins et al., 2003; Cosgrove, 2005, 2016). Roughly 40 cell types make up a plant with their cell walls determining their unique shape and function (Somerville et al., 2004; De Souza et al., 2015; Cosgrove, 2016; Chebli and Geitmann, 2017). The structurally dynamic and heterogeneous primary walls of young plant cells are predominantly comprised of cellulose microfibrils embedded in a matrix of pectin, hemicellulose, and glycoproteins (McCann et al., 1992; Somerville et al., 2004; Burton et al., 2010). Although during the last 20 years many cell wall biosynthetic enzymes have been identified, the understanding of the mechanisms facilitating polysaccharide transport is far from comprehensive. With a better understanding of cell wall component trafficking pathways, detailed models of cell wall deposition and maturation can be constructed, providing insights into the dynamic organization of cell wall during plant growth and in response to environmental cues. This review focuses on transport and deposition of cell wall components during primary cell wall formation. For a comprehensive review of secondary cell wall biosynthesis see (Meents et al., 2018).

Xyloglucan $(\mathrm{XyG})$ represents the predominant hemicellulose in the primary cell walls of eudicots and non-graminaceous monocots. XyG is a $\beta-1,4$ glucan featuring a regular pattern of substitutions 
occurring along the xylose residue on the glucan backbone. Xylose substitutions consist of galactose, O-acetylated galactose and fucose residues (Keegstra, 2010; Scheller and Ulvskov, 2010; Pauly and Keegstra, 2016; Kim et al., 2018). Pectin, a complex heterogeneous assembly of polysaccharides whose structural backbones contain galacturonic acid residues, constitutes a major part of the matrix into which cellulose microfibrils are embedded (Atmodjo et al., 2013). Both pectin and hemicellulose are synthesized by Golgi localized enzymes and thus require transport to the plasma membrane (PM), a critical yet poorly understood role of the endomembrane system. In contrast, cellulose, another key component of cell walls, is synthesized at the PM by Cellulose Synthase Complexes (CSCs) (McFarlane et al., 2014). Although the transport of pectin, hemicellulose and CSCs to the PM is currently thought to utilize the conventional ER-Golgi-trans-Golgi Network (TGN)-PM traffic route, unconventional pathways have been postulated. This review primarily focuses on TGN dependent pathways. For recent reviews on unconventional protein secretion (UPS) see (Davis et al., 2016; van de Meene et al., 2017; Wang X. et al., 2017).

\section{MULTIPLE FACTORS MAY COORDINATE TGN-MEDIATED TRANSPORT OF CELL WALL COMPONENTS}

Accurate spatial and temporal delivery of cell wall material is essential in choreographing cellular responses to the environment such as those elicited by pathogens. The endomembrane system's intricate array of molecular players orchestrates the timely delivery of cargos crucial to cell functions, and cell wall components are no exception. The TGN is the membrane compartment on the trans-side of Golgi responsible for sorting and packaging cargo molecules targeted to the PM or vacuoles (Roth et al., 1985; Griffiths and Simons, 1986; Kang et al., 2011; Rosquete et al., 2018). Unlike in other eukaryotes, plant TGN also serves as an early endosome (Dettmer et al., 2006; Viotti et al., 2010). A specialized role of the Golgi apparatus and the TGN in plants is the biosynthesis and sorting of cell wall components including biosynthetic enzymes, structural proteins and the matrix polysaccharides hemicellulose and pectin (Cosgrove, 2005; Worden et al., 2012; Kim and Brandizzi, 2016; van de Meene et al., 2017).

The function of the TGN is regulated by a plethora of factors including RAB GTPases, soluble $N$-ethylmaleimide-sensitive factor attachment protein receptors (SNAREs), tethers, accessory proteins, as well as vesicle $\mathrm{pH}$ and lipid composition (Ebine and Ueda, 2015; Zhen and Stenmark, 2015; Rosquete et al., 2018) SNARE proteins mediate membrane fusion (Ueda et al., 2012; Bombardier and Munson, 2015), with syntaxins representing a sub-family of SNAREs. Arabidopsis contains distinct syntaxins of plants (SYPs) localized to different compartments of the endomembrane system (Sanderfoot et al., 2000). SYP61, a plant SNARE interacting with SYP42/3 and VTI12 members in the TGN, appears central to the organelle's trafficking functions (Drakakaki et al., 2012; Hofmann, 2017; Li et al., 2017), discussed in depth in this review.
RAB GTPases have been shown to confer specificity to vesicle traffic and mediate membrane fusion between a donor and an acceptor compartment (Woollard and Moore, 2008; Ebine et al., 2011; Lunn et al., 2013b; Bhuin and Roy, 2014). There are 57 Arabidopsis $R A B$ genes, split into 8 clades and further classified into subclades of various sizes (Zhang et al., 2007). Vernoud et al. (2013) in trafficking of cell wall components. In a study that used Fourier transformed infrared spectroscopy to evaluate cell wall composition, the percentage of pectin, cellulose and hemicellulose within the cell wall was affected by single mutants of RABA1, RABA2, and RABA4, respectively (Lunn et al., 2013a). Based on this, the authors hypothesized specialized roles for those GTPases in the transport of specific types of polysaccharides from Golgi to the cell surface (Lunn et al., 2013a). Interestingly, RABA2, together with RABA3, has also been implied in trafficking of material to forming cell plates during cytokinesis (Chow et al., 2008) opening the question whether these two RABs are involved in the trafficking and deposition of polysaccharides at the cell plate. Though exciting, further investigation is needed into the possible specificity of these RAB GTPases (see Figure 1).

Although the roles of TGN resident tethers, adaptor proteins and vesicle lipid composition in post-Golgi protein trafficking and TGN functional compartmentalization have started to emerge, very little or nothing is known on how they regulate/impact TGN-mediated polysaccharide trafficking (Kim and Bassham, 2011; Bashline et al., 2013; Di Rubbo et al., 2013; Vukasinovic and Zarsky, 2016; Wattelet-Boyer et al., 2016; Ravikumar et al., 2017; Boutte, 2018).

\section{TRAFFICKING OF CELL WALL STRUCTURAL PROTEINS}

Structural cell wall proteins such as arabinogalactan proteins (AGPs), extensins and proline-rich proteins (PRPs) play a role in defining the cell wall's physical functional properties (Showalter and Basu, 2016a; Johnson et al., 2017a,b). However, we know very little about their location within the cell wall, their specific roles and even less about their intracellular trafficking routes. Regarding the latter, both Golgi-dependent and Golgiindependent pathways have been suggested to contribute to the secretion of cell wall proteins (Ellis et al., 2010; Tan et al., 2012; Poulsen et al., 2015; Showalter and Basu, 2016a,b).

Glycosylation is a common post-translational modification amongst PM and cell wall proteins (Nguema-Ona et al., 2014). Interestingly, a recent work combining high-resolution tandem mass spectrometry and available subcellular localization data, established links between the most prominent N-glycan structures present in a given glycoprotein and the protein's distribution in the endomembrane system, in turn reflecting the glycoprotein's trafficking pattern. The presence of complex N-glycans correlated with Golgi/PM localization while paucimannose structures were associated with extracellular glycoproteins (Zeng et al., 2018).

Arabinogalactan proteins are thought to be secreted through a Golgi-dependent pathway, supported by proteomic analysis 
of Golgi-enriched fractions (Ford et al., 2016). Contrary to this model, a study using tobacco cells detected transiently expressed AGPs glycosyltransferases in a double-membraned, Exocyst-Positive Organelle (EXPO) (Poulsen et al., 2014). EXPO has been implicated in Golgi-independent, unconventional secretion of, mostly, proteins that do not carry a signal peptide (leaderless proteins) (Wang et al., 2010; Poulsen et al., 2014, 2015; Davis et al., 2016). These findings suggest that Golgiindependent pathways may also mediate secretion of AGPs. However, such a view requires further examination as both the glycosyltransferases and the AGP protein core are not leaderless and are thus expected to follow the canonical secretory pathway.

\section{TRAFFICKING OF CELL WALL BIOSYNTHETIC AND MODIFYING ENZYMES}

The Cellulose Synthase Complexes assemble in the Golgi apparatus and are then transported to the PM, both events likely being assisted by STELLO proteins (McFarlane et al., 2014; Lampugnani et al., 2018). Tracking of CSCs at the PM has shown them moving linearly along cortical microtubules (MT) supporting the MT-cellulose alignment hypothesis (Paredez et al., 2006).

Perhaps the most studied cell wall-related trafficking process, the transport of CESAs has been proposed to be mediated by the plant specific endomembrane compartments SmaCC (small CESA compartment) and MASCs (microtubule-associated cellulose synthase compartments) (Crowell et al., 2009; Gutierrez et al., 2009). The role of MASCs/SmaCCs are involved in secretory and endocytic/ recycling routes of CESAs (Crowell et al., 2009; Gutierrez et al., 2009). Recently, the plant-specific protein PATROL1 (PTL1) and members of the exocyst complex have been associated with vesicle docking and secretion of CSCs during primary cell wall formation (Zhu et al., 2018).

Clathrin-mediated endocytosis and recycling rates influence the steady-state levels of CSCs at the PM (Bashline et al., 2013; Lei et al., 2015; Sanchez-Rodriguez et al., 2018). The plantspecific T-PLATE complex, a major adaptor module for clathrinmediated endocytosis, was recently shown to recognize CSCs for their internalization (Gadeyne et al., 2014; Sanchez-Rodriguez et al., 2018).

CESAs are cargo of the SYP61 vesicles, implicating the SYP61 TGN compartment in the post-Golgi trafficking of these enzymes (Gutierrez et al., 2009; Drakakaki et al., 2012). This is supported by the finding that CESTRIN, a small molecule that reduces the motility of CSCs at the PM, increases the association of CESAs with SYP61 vesicles (Worden et al., 2015). However, it remains unclear whether the CESAs found in the SYP61 compartment represent endocytic or secretory pools, or both. Further, CESAs secretion is affected in mutants of VHA-a1, a TGN specific proton pump isoform that partially localizes to the SYP61 compartment where it plays a prominent role in the establishment of the vesicle luminal pH (Luo et al., 2015).

Similarly to CSCs, callose biosynthesis enzymes such as Glucan Synthase-Like (GSLs) are trafficked to the PM prior to the initiation of polysaccharide synthesis (Brownfield et al., 2007, 2008; Toller et al., 2008). Not much is known about the trafficking routes of the twelve Arabidopsis GSL isoforms although several of them were identified in the proteome of SYP61 TGN/EE vesicles (Drakakaki et al., 2012). The latter suggests a canonical secretory route to the $\mathrm{PM}$, with the likely involvement of the EXOCYST tethering complex in the final event of fusion to the PM, as indicated by callose deposition studies in Arabidopsis trichomes (Kulich et al., 2018). Interestingly, trafficking of the GSL isoform PMR4 to sites of callose accumulation during the plant response to the pathogen Blumeria graminis f. sp. hordei has been suggested to occur via unconventional pathways, with the involvement of either multivesicular bodies (Bohlenius et al., 2010) or exosomes (Ellinger et al., 2013). Despite these observations, the trafficking of GSLs during different growth stages and stress conditions needs further investigation.

Cell wall associated enzymes such as apoplastic glycosidases contribute to the modification of polysaccharides during cell wall assembly creating cell wall structural diversity (Showalter, 1993; De Caroli et al., 2011; Gunl et al., 2011a,b; Sampedro et al., 2012; Frankova and Fry, 2013; Pauly and Keegstra, 2016). These proteins are thought to traffic through the secretory pathway; however, recent evidence indicates that multiple pathways may be involved. The main known cell wall modifying enzyme acting on XyG, $\beta$-GALACTOSIDASE 10 (AtBGAL10), has three distinct $\mathrm{N}$-glycosites, two with multiple high-mannose structures and the third containing paucimannose structures (Sampedro et al., 2012). Based on the presence of high-mannose structures, Zeng et al. (2018) speculated that an UPS pathway could be involved in the trafficking of $\beta$-GALACTOSIDASE 10.

Pectin methylesterase1 (AtPME1), a pectin modifying enzyme, was identified in the proteome of Golgi and also in those of SYP61 and VHA-al TGN vesicles, indicating that a Golgi-TGN route is involved in its trafficking to the PM (Drakakaki et al., 2012; Nikolovski et al., 2012; Groen et al., 2014; Heard et al., 2015). However, a different, GolgiPM pathway that bypasses TGN was identified for the trafficking of tobacco's pollen-specific NtPPME1 (Wang $\mathrm{H}$. et al., 2016).

\section{TRANSPORT OF STRUCTURAL POLYSACCHARIDES}

Compared to the number of studies that have provided insights into the secretion of cell wall biosynthetic proteins, less is known on the secretion of structural polysaccharides. Our current knowledge of cell wall polysaccharide transport results primarily from immunoelectron microscopy studies (EM) (Moore et al., 1986, 1991; Moore and Staehelin, 1988; Lynch and Staehelin, 1992; Young et al., 2008; Kang et al., 2011). However, limitations arise from the incompatibility of staining with traditional antibodies, and electron microscopy itself, with live imaging, restricting the experiments to sections of embedded tissue. Despite such limitations, a few studies have shed light into the intracellular distribution of plant polysaccharides. 


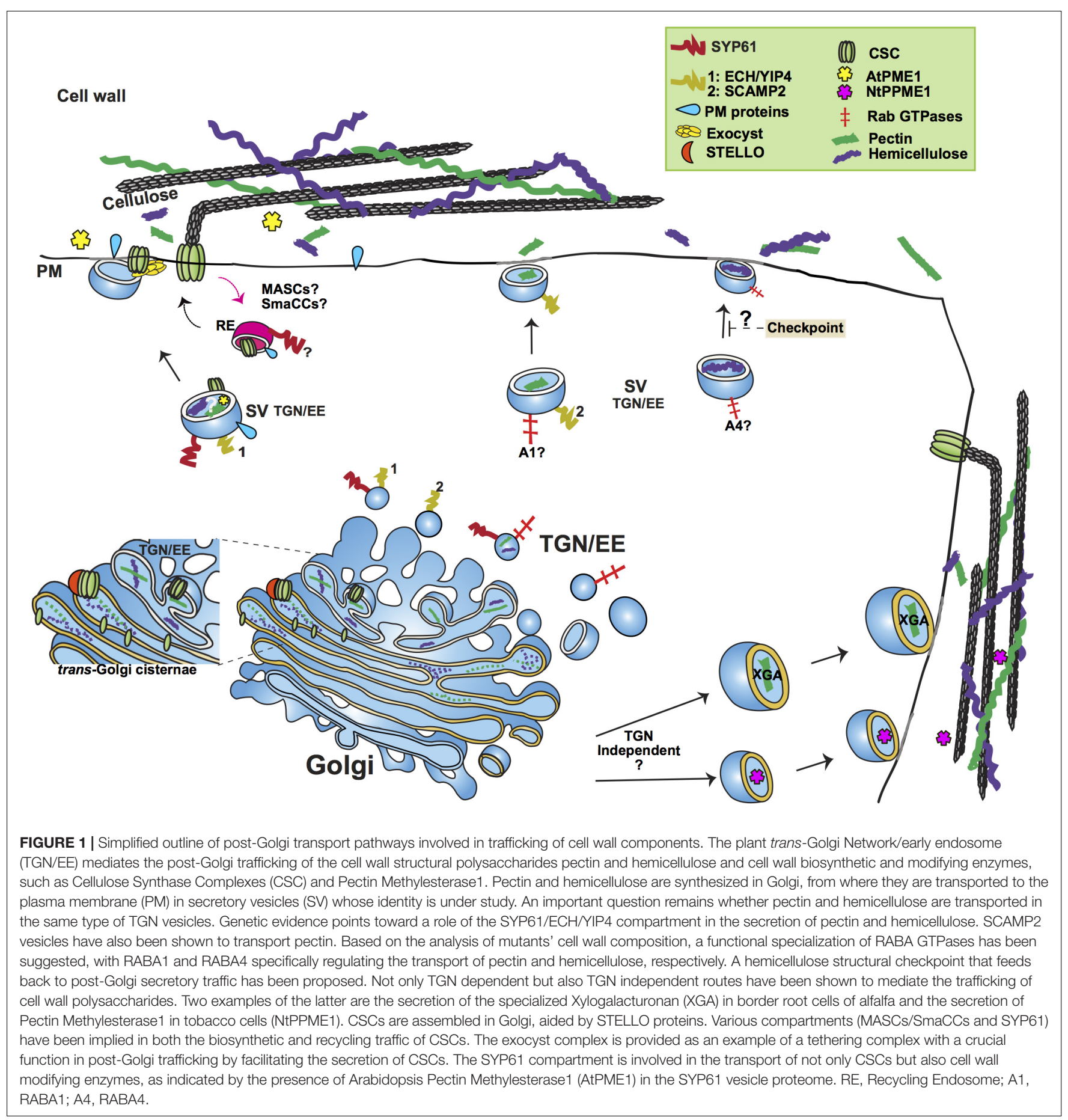

A seminal study in sycamore maple (Acer pseudoplatanus) cells detected the XyG backbone in trans-Golgi cisternae, whereas fucosylated XyG side chains were identified in both the trans cisternae and the TGN (Zhang and Staehelin, 1992). This suggests a developmental "assembly line" consisting of the initial biosynthesis of the backbone followed by the addition of side chains in Golgi sub-compartments, with the TGN transporting, mostly, fully substituted XyG (Zhang and Staehelin, 1992). In the same study, low-methylesterified pectin backbone, detected by the antibody JIM5, was found distributed in the cis- and medial-Golgi and at the cell wall whereas high-methylesterified pectin, detected by JIM7, was localized to the medial- and transGolgi, in secretory vesicles and at the cell wall. These observations indicate that pectins undergo maturation while they are delivered to the trans-Golgi, and that high-methylesterified pectin is the predominantly secreted form (Zhang and Staehelin, 1992). They also suggest that conventional post-Golgi trafficking pathways are used by both $\mathrm{XyG}$ and pectin. Importantly, the colocalization of 
XyG and pectin epitopes in transport vesicles of clover root tips indicate that TGN vesicles can potentially carry both polymers (Lynch and Staehelin, 1992).

Recent studies point to a role of cortical MTs in pectin deposition at the cell wall. Mucilage secretion was shown to be targeted to PM domains lined by abundant cortical MTs. Corroborating this observation, the temperature-sensitive MT mutant mor1-1 exhibited a decreased mucilage secretion in seeds, in the same study (McFarlane et al., 2008). In addition, the fragile Fiber1 (FRA1) kinesin has been implicated in pectin deposition (Kong Z. et al., 2015; Zhu et al., 2015).

Not surprisingly, the cell type has been shown to determine the trafficking fate of vesicles transporting cell wall polysaccharides. Xylogalacturonan (XGA), a pectin variant secreted by root border cells, is transported by distinct large vesicles, released from the trans-Golgi cisternae. XGA-loaded vesicles were shown to fuse with the PM in alfalfa border root cells but not in peripheral cells indicating the existence of regulatory mechanisms conferring cell type specificity to the trafficking and secretion of specialized polysaccharides (Wang P. et al., 2017; see Figure 1).

As aforementioned, proteomic analysis of SYP61 vesicles identified proteins involved in cell wall development (Drakakaki et al., 2012). These include the TGN-resident complex formed by ECHIDNA (ECH) and the YPT/RAB GTPase interacting Proteins $4 \mathrm{a}$ and $4 \mathrm{~b}$ (YIP4a and YIP4b), implicated in the secretion of pectin and XyG (Gendre et al., 2011, 2013). Inhibition of cell elongation and altered secretion of $\mathrm{XyG}$ and RGI pectins were shown in mutants of YIP4A, YIP4B, and ECH (Gendre et al., 2011, 2013). Further, antibodies for fucosylated XyG have been shown to label a RABA4b TGN compartment in Arabidopsis (Kang et al., 2011). Because RABA4b and SYP61 colocalize at TGN, this observation further supports a role for the SYP61 compartment in the trafficking of structural polysaccharides. The PM resident syntaxin SYNTAXIN OF PLANTS121 (SYP121) has been shown to form a SNARE complex with SYP61 mediating the secretion of PM protein cargo (Geelen et al., 2002; Hachez et al., 2014). A role for SYP121 in the secretion of SYP61 polysaccharide cargo is thus likely. Interestingly, the AtSYP121 homolog, NtSyrl, seems dispensable for polysaccharide transport in tobacco cells based on transient studies, an observation that awaits thorough testing in Arabidopsis and other plant systems (Leucci et al., 2007; see Figure 1).

Anti-pectin antibodies stain SCAMP2 (Secretory Carrier Membrane Protein 2) vesicles in tobacco BY-2 cells, suggesting the involvement of that vesicle population in the transport of pectins (Toyooka et al., 2009). The SCAMP protein structure is well conserved in eukaryotes (Law et al., 2012). In humans, SCAMP2 regulates exocytosis by forming a membrane fusion complex with the small GTPase Arf6 (ADP-ribosylation factor 6), phospholipase D1 (PLD1), and SYNTAXIN 1 (Liu et al., 2002, 2005). It is plausible that SCAMP2, via a similar mechanism, regulates exocytosis of pectin and other polysaccharide cargo in plant cells.
A role for the Exocyst complex in pectin deposition has been suggested, based on genetic evidence. Mutants of the Exocyst subunits SEC8 and EXO70A1 show reduced pectin accumulation in the seed coat. Further, reduced pectin deposition was also observed in a gain-of-function mutation of $\mathrm{ROH} 1$, an interactor of the exocyst subunit Exo70A1, supporting the involvement of this tethering factor in polysaccharide transport (Kulich et al., 2010).

Intriguingly, the structure of cell wall polysaccharides, rather than their levels, seems to influence their trafficking, as suggested by the formation of intracellular aggregates containing xyloglucan and deesterified homogalacturonan in mutants of the XyG biosynthetic enzyme galactosyltransferase MUR3 (Kong Y. et al., 2015). It is thus likely that XyG structure checkpoints that feedback to post-Golgi secretory traffic exist. Interestingly, a role for MUR3 in maintaining the organization of Golgi via its interaction with actin filaments has been suggested, hinting at a link between actin cytoskeleton and structural polysaccharides transport (Tamura et al., 2005).

\section{POLYSACCHARIDE TRANSPORT TO THE CELL PLATE}

During plant cytokinesis, a cell plate that partitions the cytoplasm of the dividing cell is formed de novo (Samuels et al., 1995; Staehelin and Hepler, 1996; Jurgens, 2005; Drakakaki, 2015). Such event requires the coordinated action of cytoskeletal transitions and endomembrane trafficking (Samuels et al., 1995; Otegui et al., 2001; Otegui and Staehelin, 2004; Segui-Simarro et al., 2004; Lee and Liu, 2013; Smertenko et al., 2017). Cell plate development occurs in four stages that exist simultaneously. It requires the directed and choreographed accumulation of postGolgi vesicles to the phragmoplast at the division plane and removal/recycling of excess material (Samuels et al., 1995; Segui-Simarro et al., 2004; Drakakaki, 2015; Smertenko et al., 2017). The deposition of cell wall polymers transforms the lumen of this membrane compartment into a new cross wall, physically separating the daughter cells (Drakakaki, 2015; Smertenko et al., 2017). Whereas a number of studies have investigated membrane dynamics (van OostendeTriplet et al., 2017), few reports exist on polysaccharide deposition and its explicit role during cell plate maturation as summarized in recent reviews (Drakakaki, 2015; Chen et al., 2018).

Vesicle trafficking during cell plate formation is controlled by many molecular players, including Rab GTPases, SNAREs, tethering factors and other regulatory proteins (reviewed in (McMichael and Bednarek, 2013; Boruc and Van Damme, 2015; Drakakaki, 2015; Smertenko et al., 2017). Two well-studied factors are RABA2A, which regulates the delivery of TGN derived vesicles to the leading edge of the cell plate (Chow et al., 2008) and the cytokinesis specific SNARE KNOLLE, which catalyzes homotypic fusion of vesicles at the cell plate (Lauber et al., 1997; Assaad et al., 2001; Heese et al., 2001; Zheng et al., 
2002; Zhang et al., 2011; El Kasmi et al., 2013; Karnahl et al., 2018).

The delivery and deposition of cell wall materials to the cell plate has been primarily studied with electron and fluorescence microscopy utilizing polysaccharide-specific antibodies. The current notion is that structural polysaccharides such as hemicellulose and pectins are transported in trans-Golgi derived secretory vesicles to the expanding and maturing cell plate (Moore and Staehelin, 1988; Samuels et al., 1995; Toyooka et al., 2009; Drakakaki, 2015). The presence of XyG is detected at early stages with enrichment in later stages (Moore and Staehelin, 1988). In Arabidopsis, the pectin backbone has been detected at the cell plate in methylesterified form (Clausen et al., 2003; Rybak et al., 2014). In red clover root tips, RGI and polygalacturonic acid labeling were observed at the middle lamella, the mature central layer of the cell plate that serves as a glue between adjacent cells. However, RGI was not detected at the early cell plate, suggesting that acidic polysaccharides may be deposited at later stages of cross wall development (Moore and Staehelin, 1988). In addition to Golgi/TGN derived polysaccharides (Moore and Staehelin, 1988), internalized pectin glycans have been implicated in cell plate formation (Baluska and Volkmann, 2002; Dhonukshe et al., 2006), a notion that awaits further investigation.

Callose and cellulose are vital luminal polysaccharides of the cell plate as supported by genetic evidence (Zuo et al., 2000; Beeckman et al., 2002; Chen et al., 2009; Thiele et al., 2009; Guseman et al., 2010; Gu et al., 2016). The relative spatiotemporal distribution of callose, cellulose and their biosynthetic enzymes during the different stages of cell plate formation is not fully elucidated. According to current thinking, callose is transiently incorporated for mechanical support during the middle/late stages of cell plate formation and is ultimately replaced by cellulose, for a more rigid luminal network (Samuels et al., 1995; Thiele et al., 2009). However, recent live imaging of cellulose synthase has shown that it accumulates at the early tubulovesicular network stage, concomitant with cellulose (Miart et al., 2014). Cell wall biosynthetic enzymes in the Cellulose Synthase Like-D family (CsID) exhibit high homology to CESAs and are also involved in cell plate formation (Gu et al., 2016). The cell cycle-regulated CslD5 is localized at early cell plate stages where it presumably produces a cellulose-like molecule, as previously shown for CslD3 in polarized root hair growth (Park et al., 2011).

Stains with both the synthetic chemical dye $\beta$-glycosyl Yariv and the monoclonal antibody LM14 have shown that AGPs, together with polysaccharides, contribute to cell plate expansion (Yu and Zhao, 2012; Rybak et al., 2014). In addition, EXTENSIN3, a hydroxyl-proline-rich glycoprotein has been implicated in cytokinesis (Hall and Cannon, 2002; Cannon et al., 2008). It is hypothesized that the self-assembled EXTENSIN network can provide mechanical support during the expansion of the cell plate, presumably via interaction with pectins (Cannon et al., 2008).

Although several endomembrane proteins have been associated with cell plate assembly, including the aforementioned SCAMP2 and the exocyst complex, little is known on their direct involvement in polysaccharide transport to the cell plate (Toyooka et al., 2009; Rybak et al., 2014).

\section{EMERGING TECHNOLOGIES TO DISSECT POLYSACCHARIDE TRANSPORT}

Live imaging of polysaccharides remains technically very challenging, making it difficult to assess the colocalization of a particular polysaccharide cargo with subcellular protein markers for specific vesicle populations. However, thanks to recent light microscopy advances that allow the use of photoactivatable and photoconvertible forms of cell wall associated proteins, combined with improved resolution imaging of carbohydrates, our knowledge of cell wall components trafficking and deposition is expected to quickly expand (Fernandez-Suarez and Ting, 2008; Toyooka and Kang, 2014; Mishin et al., 2015; Wang B. et al., 2016; Komis et al., 2018; Voiniciuc et al., 2018). In addition, field emission scanning electron microscopy (FESEM) with nanogold affinity tags affords resolution of spatial location and conformation of cell wall polymers and has proved useful to study XyG-cellulose interactions at the cell wall although this approach does not allow for live imaging (Zheng et al., 2018).

Live imaging of cell wall glycans using small oligosaccharide probes modified via click chemistry, together with polysaccharide dyes, can also contribute useful insights (Mravec et al., 2014). However, the toxicity of click chemistry reagents limits their use in live imaging experiments (Anderson et al., 2010, 2012; Wallace et al., 2012; Wang B. et al., 2016). The ever-expanding palette of metabolically labeled glycans could become a great asset for the dissection of cell wall metabolism once adapted for live imaging (Hoogenboom et al., 2016; Zhu and Chen, 2017). Cell wall glycan-directed antibodies are an elegant alternative for the identification of plant cell carbohydrates, and can be arrayed on automated large scale enzyme-linked immunosorbent assay (ELISA) platforms (glycome profiling) (Moller et al., 2008; Pattathil et al., 2010, 2012; Ruprecht et al., 2017). Cell-permeable, live imaging-compatible nanobodies represent another promising tool (Herce et al., 2017). Exemplifying their potential, a very recent study using a nanobody-epitope interaction-based protein labeling and tracking approach helped dissect a TGN/EE-to-cis-Golgi recycling pathway for vacuolar sorting receptors in Nicotiana tabacum cells (Fruholz et al., 2018).

To date, there are no suitable glycomic approaches that capture both the polysaccharide contents of specific vesicle populations and the detailed polysaccharide structures. By combining a vesicle isolation methodology, such as that established for the SYP61 compartment (Drakakaki et al., 2012), with vesicle glycome profiling, the roles of different vesicle populations in polysaccharide transport, in relation with developmental stages and responses to environmental stimuli, can be defined. In addition, glycomes of isolated vesicles, as described above, can be coupled with their respective proteomes, obtained with advanced mass spectrometry analysis (Parsons and Lilley, 2018), and with vesicle lipid composition profiling (Haraszti et al., 2016; Wattelet-Boyer et al., 2016; Boutte, 2018) 
for a better understanding of how the endomembrane system regulates cell wall transport and deposition.

Oligosaccharide mass profiling (OLIMP) utilizes specific glycosyl-hydrolases to digest cell wall polysaccharides to soluble oligosaccharides detectable by MALDI-TOF mass spectrometry (Obel et al., 2009; Gunl et al., 2010, 2011a) Analyzing Arabidopsis Golgi-enriched microsomal fractions by OLIMP showed that in the Golgi apparatus XyG oligosaccharides (XyGOs) with a lower level of xylose residue substitution by galactose and fucose are more abundant than XyGOs with a higher degree of substitution (Obel et al., 2009; Gunl et al., 2010, 2011a). However, overall this approach has limitations since it is not possible to separate contributions of the Golgi from the TGN or from endoplasmic reticulum contamination. The adequacy of OLIMP to characterize the polysaccharide cargo of specific vesicle populations has yet to be demonstrated.

Proximity tagging methods for protein localization at subcompartmental resolution, such as APEX, BioID, and SPPLAT, have the potential of not only solving the components of large protein complexes involved in cell wall biosynthesis and deposition but also their spatial distribution in membrane microdomains of subcellular compartments (Parsons and Lilley, 2018).

Further, a number of methodologies that have proved useful to study post-Golgi trafficking in other eukaryotes could be successfully implemented in the Plant field. One such method assessed the effect of ectopic intracellular localization of tethering factors on the trafficking fate of cognate vesicles

\section{REFERENCES}

Anderson, C. T., Carroll, A., Akhmetova, L., and Somerville, C. (2010). Real-time imaging of cellulose reorientation during cell wall expansion in Arabidopsis roots. Plant Physiol. 152, 787-796. doi: 10.1104/pp.109.15 0128

Anderson, C. T., Wallace, I. S., and Somerville, C. R. (2012). Metabolic clicklabeling with a fucose analog reveals pectin delivery, architecture, and dynamics in Arabidopsis cell walls. Proc. Natl. Acad. Sci. U.S.A. 109, 1329-1334. doi: 10.1073/pnas.1120429109

Assaad, F. F., Huet, Y., Mayer, U., and Jurgens, G. (2001). The cytokinesis gene KEULE encodes a Secl protein that binds the syntaxin KNOLLE. J. Cell Biol. 152, 531-543. doi: 10.1083/jcb.152.3.531

Atmodjo, M. A., Hao, Z. Y., and Mohnen, D. (2013). Evolving views of pectin biosynthesis. Annu. Rev. Plant Biol. 64, 747-749. doi: 10.1146/annurev-arplant042811-105534

Baluska, F., and Volkmann, D. (2002). Pictures in cell biology. Actin-driven polar growth of plant cells. Trends Cell Biol. 12:14. doi: 10.1016/S0962-8924(01) 02208-5

Bashline, L., Li, S., Anderson, C. T., Lei, L., and Gu, Y. (2013). The endocytosis of cellulose synthase in Arabidopsis is dependent on mu2, a clathrin-mediated endocytosis adaptin. Plant Physiol. 163, 150-160. doi: 10.1104/pp.113.22 1234

Beeckman, T., Przemeck, G. K., Stamatiou, G., Lau, R., Terryn, N., De Rycke, R., et al. (2002). Genetic complexity of cellulose synthase a gene function in Arabidopsis embryogenesis. Plant Physiol. 130, 1883-1893. doi: 10.1104/pp.102. 010603

Bhuin, T., and Roy, J. K. (2014). Rab proteins: the key regulators of intracellular vesicle transport. Exp. Cell Res. 328, 1-19. doi: 10.1016/j.yexcr.2014.07.027

Bohlenius, H., Morch, S. M., Godfrey, D., Nielsen, M. E., and ThordalChristensen, H. (2010). The multivesicular body-localized GTPase ARFA1b/1c is important for callose deposition and ROR2 syntaxin-dependent preinvasive
(Wong and Munro, 2014). A set of Golgi-localized Golgin tethers was artificially targeted to mitochondria of mammalian cells, after which their ability to redirect Golgi-bound carriers to the ectopic destination was monitored. By adapting this and other methodologies, the role and specificity of putative polysaccharide trafficking regulators can be investigated.

All these approaches offer the potential to deepen our spatiotemporal understanding and help model the highly choreographed trafficking events leading to cell wall deposition during both normal and stressful growth conditions.

\section{AUTHOR CONTRIBUTIONS}

GD, MR, and RS designed and wrote the manuscript.

\section{FUNDING}

This work was supported by NSF IOS 1258135, MCB 1818219 to GD, the USDA CA-D-PLS-2132-H, and funds from ABC PRB to GD.

\section{ACKNOWLEDGMENTS}

We apologize to our colleagues whose work we were not able to include in this review due to length limitations.

basal defense in barley. Plant Cell 22, 3831-3844. doi: 10.1105/tpc.110. 078063

Bombardier, J. P., and Munson, M. (2015). Three steps forward, two steps back: mechanistic insights into the assembly and disassembly of the SNARE complex. Curr. Opin. Chem. Biol. 29, 66-71. doi: 10.1016/j.cbpa.2015. 10.003

Boruc, J., and Van Damme, D. (2015). Endomembrane trafficking overarching cell plate formation. Curr. Opin. Plant Biol. 28, 92-98. doi: 10.1016/j.pbi.2015. 09.007

Boutte, Y. (2018). Lipids at the crossroad: shaping biological membranes heterogeneity defines trafficking pathways. PLoS Biol. 16:e2005188. doi: 10. 1371/journal.pbio.2005188

Brownfield, L., Ford, K., Doblin, M. S., Newbigin, E., Read, S., and Bacic, A. (2007). Proteomic and biochemical evidence links the callose synthase in Nicotiana alata pollen tubes to the product of the NaGSL1 gene. Plant J. 52, 147-156. doi: 10.1111/j.1365-313X.2007.03219.x

Brownfield, L., Wilson, S., Newbigin, E., Bacic, A., and Read, S. (2008). Molecular control of the glucan synthase-like protein NaGSL1 and callose synthesis during growth of Nicotiana alata pollen tubes. Biochem. J. 414, 43-52. doi: 10.1042/ BJ20080693

Burton, R. A., Gidley, M. J., and Fincher, G. B. (2010). Heterogeneity in the chemistry, structure and function of plant cell walls. Nat. Chem. Biol. 6, 724-732. doi: 10.1038/nchembio.439

Cannon, M. C., Terneus, K., Hall, Q., Tan, L., Wang, Y., Wegenhart, B. L., et al. (2008). Self-assembly of the plant cell wall requires an extensin scaffold. Proc. Natl. Acad. Sci. U.S.A. 105, 2226-2231. doi: 10.1073/pnas.0711980105

Chebli, Y., and Geitmann, A. (2017). Cellular growth in plants requires regulation of cell wall biochemistry. Curr. Opin. Cell Biol. 44, 28-35. doi: 10.1016/j.ceb. 2017.01.002

Chen, H. W., Persson, S., Grebe, M., and Mcfarlane, H. E. (2018). Cellulose synthesis during cell plate assembly. Physiol. Plant. 164, 17-26. doi: 10.1111/ ppl.12703 
Chen, X. Y., Liu, L., Lee, E., Han, X., Rim, Y., Chu, H., et al. (2009). The Arabidopsis callose synthase gene GSL8 is required for cytokinesis and cell patterning. Plant Physiol. 150, 105-113. doi: 10.1104/pp.108.133918

Chow, C. M., Neto, H., Foucart, C., and Moore, I. (2008). Rab-A2 and Rab-A3 GTPases define a trans-golgi endosomal membrane domain in Arabidopsis that contributes substantially to the cell plate. Plant Cell 20, 101-123. doi: 10.1105/tpc.107.052001

Clausen, M. H., Willats, W. G., and Knox, J. P. (2003). Synthetic methyl hexagalacturonate hapten inhibitors of anti-homogalacturonan monoclonal antibodies LM7, JIM5 and JIM7. Carbohydr. Res. 338, 1797-1800. doi: 10.1016/ S0008-6215(03)00272-6

Collins, N. C., Thordal-Christensen, H., Lipka, V., Bau, S., Kombrink, E., Qiu, J. L., et al. (2003). SNARE-protein-mediated disease resistance at the plant cell wall. Nature 425, 973-977. doi: 10.1038/nature02076

Cosgrove, D. J. (2005). Growth of the plant cell wall. Nat. Rev. Mol. Cell Biol. 6, 850-861. doi: 10.1038/nrm 1746

Cosgrove, D. J. (2016). Plant cell wall extensibility: connecting plant cell growth with cell wall structure, mechanics, and the action of wall-modifying enzymes. J. Exp. Bot. 67, 463-476. doi: 10.1093/jxb/erv511

Crowell, E. F., Bischoff, V., Desprez, T., Rolland, A., Stierhof, Y. D., Schumacher, K., et al. (2009). Pausing of Golgi bodies on microtubules regulates secretion of cellulose synthase complexes in Arabidopsis. Plant Cell 21, 1141-1154. doi: 10.1105/tpc.108.065334

Davis, D. J., Kang, B. H., Heringer, A. S., Wilkop, T. E., and Drakakaki, G. (2016). Unconventional protein secretion in plants. Methods Mol. Biol. 1459, 47-63. doi: 10.1007/978-1-4939-3804-9_3

De Caroli, M., Lenucci, M. S., Di Sansebastiano, G. P., Dalessandro, G., De Lorenzo, G., and Piro, G. (2011). Protein trafficking to the cell wall occurs through mechanisms distinguishable from default sorting in tobacco. Plant J. 65, 295-308. doi: 10.1111/j.1365-313X.2010.04421.x

De Souza, A. P., Alvim Kamei, C. L., Torres, A. F., Pattathil, S., Hahn, M. G., Trindade, L. M., et al. (2015). How cell wall complexity influences saccharification efficiency in Miscanthus sinensis. J. Exp. Bot. 66, 4351-4365. doi: $10.1093 /$ jxb/erv183

Dettmer, J., Hong-Hermesdorf, A., Stierhof, Y. D., and Schumacher, K. (2006). Vacuolar H+-ATPase activity is required for endocytic and secretory trafficking in Arabidopsis. Plant Cell 18, 715-730. doi: 10.1105/tpc.105.037978

Dhonukshe, P., Baluska, F., Schlicht, M., Hlavacka, A., Samaj, J., Friml, J., et al. (2006). Endocytosis of cell surface material mediates cell plate formation during plant cytokinesis. Dev. Cell 10, 137-150. doi: 10.1016/j.devcel.2005. 11.015

Di Rubbo, S., Irani, N. G., Kim, S. Y., Xu, Z. Y., Gadeyne, A., Dejonghe, W., et al. (2013). The clathrin adaptor complex AP-2 mediates endocytosis of brassinosteroid insensitive1 in Arabidopsis. Plant Cell 25, 2986-2997. doi: 10. 1105/tpc.113.114058

Drakakaki, G. (2015). Polysaccharide deposition during cytokinesis: challenges and future perspectives. Plant Sci. 236, 177-184. doi: 10.1016/j.plantsci.2015.03.018

Drakakaki, G., Van De Ven, W., Pan, S., Miao, Y., Wang, J., Keinath, N. F., et al. (2012). Isolation and proteomic analysis of the SYP61 compartment reveal its role in exocytic trafficking in Arabidopsis. Cell Res. 22, 413-424. doi: 10.1038/ cr.2011.129

Ebine, K., Fujimoto, M., Okatani, Y., Nishiyama, T., Goh, T., Ito, E., et al. (2011). A membrane trafficking pathway regulated by the plant-specific RAB GTPase ARA6. Nat. Cell Biol. 13, 853-859. doi: 10.1038/ncb2270

Ebine, K., and Ueda, T. (2015). Roles of membrane trafficking in plant cell wall dynamics. Front. Plant Sci. 6:878. doi: 10.3389/fpls.2015.00878

El Kasmi, F., Krause, C., Hiller, U., Stierhof, Y. D., Mayer, U., Conner, L., et al. (2013). SNARE complexes of different composition jointly mediate membrane fusion in Arabidopsis cytokinesis. Mol. Biol. Cell 24, 1593-1601. doi: 10.1091/ mbc.E13-02-0074

Ellinger, D., Naumann, M., Falter, C., Zwikowics, C., Jamrow, T., Manisseri, C., et al. (2013). Elevated early callose deposition results in complete penetration resistance to powdery mildew in Arabidopsis. Plant Physiol. 161, 1433-1444. doi: 10.1104/pp.112.211011

Ellis, M., Egelund, J., Schultz, C. J., and Bacic, A. (2010). Arabinogalactan-proteins: key regulators at the cell surface? Plant Physiol. 153, 403-419. doi: 10.1104/pp. 110.156000
Fernandez-Suarez, M., and Ting, A. Y. (2008). Fluorescent probes for superresolution imaging in living cells. Nat. Rev. Mol. Cell Biol. 9, 929-943. doi: $10.1038 / \mathrm{nrm} 2531$

Ford, K. L., Chin, T., Srivastava, V., Zeng, W., Doblin, M. S., Bulone, V., et al. (2016). Comparative "Golgi" proteome study of Lolium multiflorum and Populus trichocarpa. Proteomes 4:E23. doi: 10.3390/proteomes4030023

Frankova, L., and Fry, S. C. (2013). Biochemistry and physiological roles of enzymes that 'cut and paste' plant cell-wall polysaccharides. J. Exp. Bot. 64, 3519-3550. doi: 10.1093/jxb/ert201

Fruholz, S., Fassler, F., Kolukisaoglu, U., and Pimpl, P. (2018). Nanobody-triggered lockdown of VSRs reveals ligand reloading in the Golgi. Nat. Commun. 9:643. doi: 10.1038/s41467-018-02909-6

Gadeyne, A., Sanchez-Rodriguez, C., Vanneste, S., Di Rubbo, S., Zauber, H., Vanneste, K., et al. (2014). The TPLATE adaptor complex drives clathrinmediated endocytosis in plants. Cell 156, 691-704. doi: 10.1016/j.cell.2014. 01.039

Geelen, D., Leyman, B., Batoko, H., Di Sansebastiano, G. P., Moore, I., and Blatt, M. R. (2002). The abscisic acid-related SNARE homolog NtSyrl contributes to secretion and growth: evidence from competition with its cytosolic domain. Plant Cell 14, 387-406. doi: 10.1105/tpc.010328

Gendre, D., Mcfarlane, H. E., Johnson, E., Mouille, G., Sjodin, A., Oh, J., et al. (2013). Trans-Golgi network localized ECHIDNA/Ypt interacting protein complex is required for the secretion of cell wall polysaccharides in Arabidopsis. Plant Cell 25, 2633-2646. doi: 10.1105/tpc.113.112482

Gendre, D., Oh, J., Boutte, Y., Best, J. G., Samuels, L., Nilsson, R., et al. (2011). Conserved Arabidopsis ECHIDNA protein mediates trans-Golgi-network trafficking and cell elongation. Proc. Natl. Acad. Sci. U.S.A. 108, 8048-8053. doi: $10.1073 /$ pnas. 1018371108

Griffiths, G., and Simons, K. (1986). The trans Golgi network: sorting at the exit site of the Golgi complex. Science 234, 438-443. doi: 10.1126/science.2945253

Groen, A. J., Sancho-Andres, G., Breckels, L. M., Gatto, L., Aniento, F., and Lilley, K. S. (2014). Identification of trans-golgi network proteins in Arabidopsis thaliana root tissue. J. Proteome Res. 13, 763-776. doi: 10.1021/pr4008464

Gu, F., Bringmann, M., Combs, J. R., Yang, J., Bergmann, D. C., and Nielsen, E. (2016). Arabidopsis CSLD5 functions in cell plate formation in a cell cycledependent manner. Plant Cell 28, 1722-1737. doi: 10.1105/tpc.16.00203

Gunl, M., Gille, S., and Pauly, M. (2010). OLIgo mass profiling (OLIMP) of extracellular polysaccharides. J. Vis. Exp. 40:2046. doi: 10.3791/2046

Gunl, M., Kraemer, F., and Pauly, M. (2011a). Oligosaccharide mass profiling (OLIMP) of cell wall polysaccharides by MALDI-TOF/MS. Methods Mol. Biol. 715, 43-54. doi: 10.1007/978-1-61779-008-9_3

Gunl, M., Neumetzler, L., Kraemer, F., De Souza, A., Schultink, A., Pena, M., et al. (2011b). AXY8 encodes an alpha-fucosidase, underscoring the importance of apoplastic metabolism on the fine structure of Arabidopsis cell wall polysaccharides. Plant Cell 23, 4025-4040. doi: 10.1105/tpc.111.089193

Guseman, J. M., Lee, J. S., Bogenschutz, N. L., Peterson, K. M., Virata, R. E., Xie, B., et al. (2010). Dysregulation of cell-to-cell connectivity and stomatal patterning by loss-of-function mutation in Arabidopsis CHORUS (GLUCAN SYNTHASE-LIKE 8). Development 137, 1731-1741. doi: 10.1242/dev. 049197

Gutierrez, R., Lindeboom, J. J., Paredez, A. R., Emons, A. M., and Ehrhardt, D. W. (2009). Arabidopsis cortical microtubules position cellulose synthase delivery to the plasma membrane and interact with cellulose synthase trafficking compartments. Nat. Cell Biol. 11, 797-806. doi: 10.1038/ncb1886

Hachez, C., Laloux, T., Reinhardt, H., Cavez, D., Degand, H., Grefen, C., et al. (2014). Arabidopsis SNAREs SYP61 and SYP121 coordinate the trafficking of plasma membrane aquaporin PIP2;7 to modulate the cell membrane water permeability. Plant Cell 26, 3132-3147. doi: 10.1105/tpc.114.127159

Hall, Q., and Cannon, M. C. (2002). The cell wall hydroxyproline-rich glycoprotein RSH is essential for normal embryo development in Arabidopsis. Plant Cell 14, 1161-1172. doi: 10.1105/tpc.010477

Haraszti, R. A., Didiot, M. C., Sapp, E., Leszyk, J., Shaffer, S. A., Rockwell, H. E., et al. (2016). High-resolution proteomic and lipidomic analysis of exosomes and microvesicles from different cell sources. J. Extracell Vesicles 5:32570. doi: 10.3402/jev.v5.32570

Heard, W., Sklenar, J., Tome, D. F., Robatzek, S., and Jones, A. M. (2015). Identification of regulatory and cargo proteins of endosomal and secretory 
pathways in Arabidopsis thaliana by proteomic dissection. Mol. Cell. Proteomics 14, 1796-1813. doi: 10.1074/mcp.M115.050286

Heese, M., Gansel, X., Sticher, L., Wick, P., Grebe, M., Granier, F., et al. (2001). Functional characterization of the KNOLLE-interacting t-SNARE AtSNAP33 and its role in plant cytokinesis. J. Cell Biol. 155, 239-249. doi: 10.1083/jcb. 200107126

Herce, H. D., Schumacher, D., Schneider, A. F. L., Ludwig, A. K., Mann, F. A., Fillies, M., et al. (2017). Cell-permeable nanobodies for targeted immunolabelling and antigen manipulation in living cells. Nat. Chem. 9, 762 771. doi: $10.1038 /$ nchem. 2811

Hofmann, N. R. (2017). Basal versus nonbasal polarity: different endomembrane trafficking pathways establish different patterns. Plant Cell 29:1. doi: 10.1105/ tpc.17.00065

Hoogenboom, J., Berghuis, N., Cramer, D., Geurts, R., Zuilhof, H., and Wennekes, T. (2016). Direct imaging of glycans in Arabidopsis roots via click labeling of metabolically incorporated azido-monosaccharides. BMC Plant Biol. 16:220. doi: 10.1186/s12870-016-0907-0

Johnson, K. L., Cassin, A. M., Lonsdale, A., Bacic, A., Doblin, M. S., and Schultz, C. J. (2017a). Pipeline to identify hydroxyproline-rich glycoproteins. Plant Physiol. 174, 886-903. doi: 10.1104/pp.17.00294

Johnson, K. L., Cassin, A. M., Lonsdale, A., Wong, G. K., Soltis, D. E., Miles, N. W., et al. (2017b). Insights into the evolution of hydroxyproline-rich glycoproteins from 1000 plant transcriptomes. Plant Physiol. 174, 904-921. doi: 10.1104/pp. 17.00295

Jurgens, G. (2005). Cytokinesis in higher plants. Annu. Rev. Plant Biol. 56, 281-299. doi: 10.1146/annurev.arplant.55.031903.141636

Kang, B. H., Nielsen, E., Preuss, M. L., Mastronarde, D., and Staehelin, L. A. (2011). Electron tomography of RabA4b- and PI-4Kbeta1-labeled trans Golgi network compartments in Arabidopsis. Traffic 12, 313-329. doi: 10.1111/j.1600-0854. 2010.01146.x

Karnahl, M., Park, M., Krause, C., Hiller, U., Mayer, U., Stierhof, Y. D., et al. (2018). Functional diversification of Arabidopsis SEC1-related SM proteins in cytokinetic and secretory membrane fusion. Proc. Natl. Acad. Sci. U.S.A. 115, 6309-6314. doi: 10.1073/pnas.1722611115

Keegstra, K. (2010). Plant cell walls. Plant Physiol. 154, 483-486. doi: 10.1104/pp. 110.161240

Kim, S. J., and Bassham, D. C. (2011). TNO1 is involved in salt tolerance and vacuolar trafficking in Arabidopsis. Plant Physiol. 156, 514-526. doi: 10.1104/ pp. 110.168963

Kim, S. J., and Brandizzi, F. (2016). The plant secretory pathway for the trafficking of cell wall polysaccharides and glycoproteins. Glycobiology 26, 940-949. doi: 10.1093/glycob/cww044

Kim, S. J., Zemelis-Durfee, S., Jensen, J. K., Wilkerson, C. G., Keegstra, K., and Brandizzi, F. (2018). In the grass species Brachypodium distachyon, the production of mixed-linkage $(1,3 ; 1,4)$-beta-glucan (MLG) occurs in the Golgi apparatus. Plant J. 93, 1062-1075. doi: 10.1111/tpj.13830

Komis, G., Novak, D., Ovecka, M., Samajova, O., and Samaj, J. (2018). Advances in imaging plant cell dynamics. Plant Physiol. 176, 80-93. doi: 10.1104/pp.17. 00962

Kong, Y., Peña, M. J., Renna, L., Avci, U., Pattathil, S., Tuomivaara, S. T., et al. (2015). Galactose-depleted xyloglucan is dysfunctional and leads to dwarfism in Arabidopsis. Plant Physiol. 167, 1296-1306. doi: 10.1104/pp.114.25 5943

Kong, Z., Ioki, M., Braybrook, S., Li, S., Ye, Z.-H., Julie Lee, Y.-R., et al. (2015). Kinesin-4 functions in vesicular transport on cortical microtubules and regulates cell wall mechanics during cell elongation in plants. Mol. Plant 8, 1011-1023. doi: 10.1016/j.molp.2015.01.004

Kulich, I., Cole, R., Drdova, E., Cvrckova, F., Soukup, A., Fowler, J., et al. (2010). Arabidopsis exocyst subunits SEC8 and EXO70A1 and exocyst interactor $\mathrm{ROH} 1$ are involved in the localized deposition of seed coat pectin. New Phytol. 188, 615-625. doi: 10.1111/j.1469-8137.2010.03372.x

Kulich, I., Vojtikova, Z., Sabol, P., Ortmannova, J., Nedela, V., Tihlarikova, E., et al. (2018). Exocyst Subunit EXO70H4 has a specific role in callose synthase secretion and silica accumulation. Plant Physiol. 176, 2040-2051. doi: 10.1104/ pp.17.01693

Lampugnani, E. R., Khan, G. A., Somssich, M., and Persson, S. (2018). Building a plant cell wall at a glance. J. Cell Sci. 131:jcs207373. doi: 10.1242/jcs.207373
Lauber, M. H., Waizenegger, I., Steinmann, T., Schwarz, H., Mayer, U., Hwang, I., et al. (1997). The Arabidopsis KNOLLE protein is a cytokinesis-specific syntaxin. J. Cell Biol. 139, 1485-1493. doi: 10.1083/jcb.139.6.1485

Law, A. H., Chow, C. M., and Jiang, L. (2012). Secretory carrier membrane proteins. Protoplasma 249, 269-283. doi: 10.1007/s00709-011-0295-0

Lee, Y. R., and Liu, B. (2013). The rise and fall of the phragmoplast microtubule array. Curr. Opin. Plant Biol. 16, 757-763. doi: 10.1016/j.pbi.2013.10.008

Lei, L., Singh, A., Bashline, L., Li, S., Yingling, Y. G., and Gu, Y. (2015). CELLULOSE SYNTHASE INTERACTIVE1 is required for fast recycling of cellulose synthase complexes to the plasma membrane in Arabidopsis. Plant Cell 27, 2926-2940. doi: 10.1105/tpc.15.00442

Leucci, M. R., Di Sansebastiano, G. P., Gigante, M., Dalessandro, G., and Piro, G. (2007). Secretion marker proteins and cell-wall polysaccharides move through different secretory pathways. Planta 225, 1001-1017. doi: 10.1007/s00425-0060407-9

Li, R., Rodriguez-Furlan, C., Wang, J., Van De Ven, W., Gao, T., Raikhel, N. V., et al. (2017). Different Endomembrane trafficking pathways establish apical and basal polarities. Plant Cell 29, 90-108. doi: 10.1105/tpc.16.00524

Liu, L., Guo, Z., Tieu, Q., Castle, A., and Castle, D. (2002). Role of secretory carrier membrane protein SCAMP2 in granule exocytosis. Mol. Biol. Cell 13, 4266-4278. doi: 10.1091/mbc.e02-03-0136

Liu, L., Liao, H., Castle, A., Zhang, J., Casanova, J., Szabo, G., et al. (2005). SCAMP2 interacts with Arf6 and phospholipase D1 and links their function to exocytotic fusion pore formation in PC12 cells. Mol. Biol. Cell 16, 4463-4472. doi: 10.1091/mbc.e05-03-0231

Lunn, D., Gaddipati, S. R., Tucker, G. A., and Lycett, G. W. (2013a). Null mutants of individual RABA genes impact the proportion of different cell wall components in stem tissue of Arabidopsis thaliana. PLoS One 8:e75724. doi: 10.1371/journal. pone. 0075724

Lunn, D., Phan, T. D., Tucker, G. A., and Lycett, G. W. (2013b). Cell wall composition of tomato fruit changes during development and inhibition of vesicle trafficking is associated with reduced pectin levels and reduced softening. Plant Physiol. Biochem. 66, 91-97. doi: 10.1016/j.plaphy.2013.02.005

Luo, Y., Scholl, S., Doering, A., Zhang, Y., Irani, N. G., Di Rubbo, S., et al. (2015). V-ATPase activity in the TGN/EE is required for exocytosis and recycling in Arabidopsis. Nat. Plants 1:15094. doi: 10.1038/nplants.2015.94

Lynch, M. A., and Staehelin, L. A. (1992). Domain-specific and cell type-specific localization of two types of cell wall matrix polysaccharides in the clover root tip. J. Cell Biol. 118, 467-479. doi: 10.1083/jcb.118.2.467

McCann, M. C., Wells, B., and Roberts, K. (1992). Complexity in the spatial localization and length distribution of plant cell-wall matrix polysaccharides. J. Microscopy Oxford 166, 123-136. doi: 10.1111/j.1365-2818.1992.tb01511.x

McFarlane, H. E., Doring, A., and Persson, S. (2014). The cell biology of cellulose synthesis. Annu. Rev. Plant Biol. 65, 69-94. doi: 10.1146/annurev-arplant050213-040240

McFarlane, H. E., Young, R. E., Wasteneys, G. O., and Samuels, A. L. (2008). Cortical microtubules mark the mucilage secretion domain of the plasma membrane in Arabidopsis seed coat cells. Planta 227, 1363-1375. doi: 10.1007/ s00425-008-0708-2

McMichael, C. M., and Bednarek, S. Y. (2013). Cytoskeletal and membrane dynamics during higher plant cytokinesis. New Phytol. 197, 1039-1057. doi: $10.1111 /$ nph.12122

Meents, M. J., Watanabe, Y., and Samuels, A. L. (2018). The cell biology of secondary cell wall biosynthesis. Ann. Bot. 121, 1107-1125. doi: 10.1093/aob/ mcy005

Miart, F., Desprez, T., Biot, E., Morin, H., Belcram, K., Hofte, H., et al. (2014). Spatio-temporal analysis of cellulose synthesis during cell plate formation in Arabidopsis. Plant J. 77, 71-84. doi: 10.1111/tpj.12362

Mishin, A. S., Belousov, V. V., Solntsev, K. M., and Lukyanov, K. A. (2015). Novel uses of fluorescent proteins. Curr. Opin. Chem. Biol. 27, 1-9. doi: 10.1016/j.cbpa. 2015.05.002

Moller, I., Marcus, S. E., Haeger, A., Verhertbruggen, Y., Verhoef, R., Schols, H., et al. (2008). High-throughput screening of monoclonal antibodies against plant cell wall glycans by hierarchical clustering of their carbohydrate microarray binding profiles. Glycoconj. J. 25, 37-48. doi: 10.1007/s10719-007-9059-7

Moore, P. J., Darvill, A. G., Albersheim, P., and Staehelin, L. A. (1986). Immunogold localization of xyloglucan and rhamnogalacturonan $\mathrm{I}$ in the cell 
walls of suspension-cultured sycamore cells. Plant Physiol. 82, 787-794. doi: 10.1104/pp.82.3.787

Moore, P. J., and Staehelin, L. A. (1988). Immunogold localization of the cellwall-matrix polysaccharides rhamnogalacturonan I and xyloglucan during cell expansion and cytokinesis in Trifolium pratense L.; implication for secretory pathways. Planta 174, 433-445. doi: 10.1007/BF00634471

Moore, P. J., Swords, K. M., Lynch, M. A., and Staehelin, L. A. (1991). Spatial organization of the assembly pathways of glycoproteins and complex polysaccharides in the Golgi apparatus of plants. J. Cell Biol. 112, 589-602. doi: $10.1083 /$ jcb.112.4.589

Mravec, J., Kracun, S. K., Rydahl, M. G., Westereng, B., Miart, F., Clausen, M. H., et al. (2014). Tracking developmentally regulated post-synthetic processing of homogalacturonan and chitin using reciprocal oligosaccharide probes. Development 141, 4841-4850. doi: 10.1242/dev.113365

Nguema-Ona, E., Vicre-Gibouin, M., Gotte, M., Plancot, B., Lerouge, P., Bardor, M., et al. (2014). Cell wall O-glycoproteins and N-glycoproteins: aspects of biosynthesis and function. Front. Plant Sci. 5:499. doi: 10.3389/fpls.2014. 00499

Nikolovski, N., Rubtsov, D., Segura, M. P., Miles, G. P., Stevens, T. J., Dunkley, T. P., et al. (2012). Putative glycosyltransferases and other plant golgi apparatus proteins are revealed by LOPIT proteomics. Plant Physiol. 160, 1037-1051. doi: 10.1104/pp.112.204263

Obel, N., Erben, V., Schwarz, T., Kuhnel, S., Fodor, A., and Pauly, M. (2009). Microanalysis of plant cell wall polysaccharides. Mol. Plant 2, 922-932. doi: $10.1093 / \mathrm{mp} / \mathrm{ssp} 046$

Otegui, M. S., Mastronarde, D. N., Kang, B. H., Bednarek, S. Y., and Staehelin, L. A. (2001). Three-dimensional analysis of syncytial-type cell plates during endosperm cellularization visualized by high resolution electron tomography. Plant Cell 13, 2033-2051. doi: 10.1105/tpc.13.9.2033

Otegui, M. S., and Staehelin, L. A. (2004). Electron tomographic analysis of postmeiotic cytokinesis during pollen development in Arabidopsis thaliana. Planta 218, 501-515. doi: 10.1007/s00425-003-1125-1

Paredez, A. R., Somerville, C. R., and Ehrhardt, D. W. (2006). Visualization of cellulose synthase demonstrates functional association with microtubules. Science 312, 1491-1495. doi: 10.1126/science.1126551

Park, S., Szumlanski, A. L., Gu, F., Guo, F., and Nielsen, E. (2011). A role for CSLD3 during cell-wall synthesis in apical plasma membranes of tip-growing root-hair cells. Nat. Cell Biol. 13, 973-980. doi: 10.1038/ncb2294

Parsons, H. T., and Lilley, K. S. (2018). Mass spectrometry approaches to study plant endomembrane trafficking. Semin. Cell Dev. Biol. 80, 123-132. doi: 10. 1016/j.semcdb.2017.10.014

Pattathil, S., Avci, U., Baldwin, D., Swennes, A. G., Mcgill, J. A., Popper, Z., et al. (2010). A comprehensive toolkit of plant cell wall glycan-directed monoclonal antibodies. Plant Physiol. 153, 514-525. doi: 10.1104/pp.109.151985

Pattathil, S., Avci, U., Miller, J. S., and Hahn, M. G. (2012). Immunological approaches to plant cell wall and biomass characterization: glycome profiling. Methods Mol. Biol. 908, 61-72. doi: 10.1007/978-1-61779956-3_6

Pauly, M., and Keegstra, K. (2016). Biosynthesis of the plant cell wall matrix Polysaccharide Xyloglucan. Annu. Rev. Plant Biol. 67, 235-259. doi: 10.1146/ annurev-arplant-043015-112222

Poulsen, C. P., Dilokpimol, A., and Geshi, N. (2015). Arabinogalactan biosynthesis: implication of AtGALT29A enzyme activity regulated by phosphorylation and co-localized enzymes for nucleotide sugar metabolism in the compartments outside of the Golgi apparatus. Plant Signal. Behav. 10:e984524. doi: 10.4161/ 15592324.2014.984524

Poulsen, C. P., Dilokpimol, A., Mouille, G., Burow, M., and Geshi, N. (2014). Arabinogalactan glycosyltransferases target to a unique subcellular compartment that may function in unconventional secretion in plants. Traffic 15, 1219-1234. doi: 10.1111/tra.12203

Ravikumar, R., Steiner, A., and Assaad, F. F. (2017). Multisubunit tethering complexes in higher plants. Curr. Opin. Plant Biol. 40, 97-105. doi: 10.1016/ j.pbi.2017.08.009

Rosquete, M. R., Davis, D. J., and Drakakaki, G. (2018). The plant trans-golgi network: not just a matter of distinction. Plant Physiol. 176, 187-198. doi: 10.1104/pp.17.01239

Roth, J., Taatjes, D. J., Lucocq, J. M., Weinstein, J., and Paulson, J. C. (1985). Demonstration of an extensive trans-tubular network continuous with the
Golgi apparatus stack that may function in glycosylation. Cell 43, 287-295. doi: 10.1016/0092-8674(85)90034-0

Ruprecht, C., Bartetzko, M. P., Senf, D., Dallabernadina, P., Boos, I., Andersen, M. C. F., et al. (2017). A synthetic glycan microarray enables epitope mapping of plant cell wall glycan-directed antibodies. Plant Physiol. 175, 1094-1104. doi: $10.1104 /$ pp.17.00737

Rybak, K., Steiner, A., Synek, L., Klaeger, S., Kulich, I., Facher, E., et al. (2014). Plant cytokinesis is orchestrated by the sequential action of the TRAPPII and exocyst tethering complexes. Dev. Cell 29, 607-620. doi: 10.1016/j.devcel.2014.04.029

Sampedro, J., Gianzo, C., Iglesias, N., Guitian, E., Revilla, G., and Zarra, I. (2012). AtBGAL10 is the main xyloglucan beta-galactosidase in Arabidopsis, and its absence results in unusual xyloglucan subunits and growth defects. Plant Physiol. 158, 1146-1157. doi: 10.1104/pp.111.192195

Samuels, A. L., Giddings, T. H. Jr., and Staehelin, L. A. (1995). Cytokinesis in tobacco BY-2 and root tip cells: a new model of cell plate formation in higher plants. J. Cell Biol. 130, 1345-1357. doi: 10.1083/jcb.130.6.1345

Sanchez-Rodriguez, C., Shi, Y., Kesten, C., Zhang, D., Sancho-Andres, G., Ivakov, A., et al. (2018). The cellulose synthases are cargo of the TPLATE adaptor complex. Mol. Plant 11, 346-349. doi: 10.1016/j.molp.2017.11.012

Sanderfoot, A. A., Assaad, F. F., and Raikhel, N. V. (2000). The Arabidopsis genome. An abundance of soluble N-ethylmaleimide-sensitive factor adaptor protein receptors. Plant Physiol. 124, 1558-1569. doi: 10.1104/pp.124.4. 1558

Scheller, H. V., and Ulvskov, P. (2010). Hemicelluloses. Annu. Rev. Plant Biol. 61, 263-289. doi: 10.1146/annurev-arplant-042809-112315

Segui-Simarro, J. M., Austin, J. R., White, E. A., and Staehelin, L. A. (2004). Electron tomographic analysis of somatic cell plate formation in meristematic cells of Arabidopsis preserved by high-pressure freezing. Plant Cell 16, 836-856. doi: $10.1105 /$ tpc.017749

Showalter, A. M. (1993). Structure and function of plant cell wall proteins. Plant Cell 5, 9-23. doi: 10.1105/tpc.5.1.9

Showalter, A. M., and Basu, D. (2016a). Extensin and arabinogalactan-protein biosynthesis: glycosyltransferases, research challenges, and biosensors. Front. Plant Sci. 7:814. doi: 10.3389/fpls.2016.00814

Showalter, A. M., and Basu, D. (2016b). Glycosylation of arabinogalactan-proteins essential for development in Arabidopsis. Commun. Integr. Biol. 9:e1177687. doi: 10.1080/19420889.2016.1177687

Smertenko, A., Assaad, F., Baluska, F., Bezanilla, M., Buschmann, H. Drakakaki, G., et al. (2017). Plant cytokinesis: terminology for structures and processes. Trends Cell Biol. 27, 885-894. doi: 10.1016/j.tcb.2017. 08.008

Somerville, C., Bauer, S., Brininstool, G., Facette, M., Hamann, T., Milne, J., et al. (2004). Toward a systems approach to understanding plant cell walls. Science 306, 2206-2211. doi: 10.1126/science.1102765

Staehelin, L. A., and Hepler, P. K. (1996). Cytokinesis in higher plants. Cell 84, 821-824. doi: 10.1016/S0092-8674(00)81060-0

Tamura, K., Shimada, T., Kondo, M., Nishimura, M., and Hara-Nishimura, I. (2005). KATAMARI1/MURUS3 is a novel Golgi membrane protein that is required for endomembrane organization in Arabidopsis. Plant Cell 17, 17641776. doi: 10.1105/tpc.105.031930

Tan, L., Showalter, A. M., Egelund, J., Hernandez-Sanchez, A., Doblin, M. S., and Bacic, A. (2012). Arabinogalactan-proteins and the research challenges for these enigmatic plant cell surface proteoglycans. Front. Plant Sci. 3:140. doi: $10.3389 /$ fpls.2012.00140

Thiele, K., Wanner, G., Kindzierski, V., Jurgens, G., Mayer, U., Pachl, F., et al. (2009). The timely deposition of callose is essential for cytokinesis in Arabidopsis. Plant J. 58, 13-26. doi: 10.1111/j.1365-313X.2008.03760.x

Toller, A., Brownfield, L., Neu, C., Twell, D., and Schulze-Lefert, P. (2008). Dual function of Arabidopsis glucan synthase-like genes GSL8 and GSL10 in male gametophyte development and plant growth. Plant J. 54, 911-923. doi: 10.1111/ j.1365-313X.2008.03462.x

Toyooka, K., Goto, Y., Asatsuma, S., Koizumi, M., Mitsui, T., and Matsuoka, K. (2009). A mobile secretory vesicle cluster involved in mass transport from the Golgi to the plant cell exterior. Plant Cell 21, 1212-1229. doi: 10.1105/tpc.108. 058933

Toyooka, K., and Kang, B. H. (2014). Reconstructing plant cells in 3D by serial section electron tomography. Methods Mol. Biol. 1080, 159-170. doi: 10.1007/ 978-1-62703-643-6_13 
Ueda, T., Sato, M. H., and Uemura, T. (2012). "The Role of RAB GTPases and SNARE proteins in plant endocytosis and post-golgi trafficking," in Endocytosis in Plants, ed. J. Šamaj (Berlin: Springer), 201-216.

van de Meene, A. M., Doblin, M. S., and Bacic, A. (2017). The plant secretory pathway seen through the lens of the cell wall. Protoplasma 254, 75-94. doi: 10.1007/s00709-016-0952-4

van Oostende-Triplet, C., Guillet, D., Triplet, T., Pandzic, E., Wiseman, P. W., and Geitmann, A. (2017). Vesicle dynamics during plant cell cytokinesis reveals distinct developmental phases. Plant Physiol. 174, 1544-1558. doi: 10.1104/pp. 17.00343

Vernoud, V., Horton, A. C., Yang, Z., and Nielsen, E. (2013). Analysis of the small GTPase gene superfamily of Arabidopsis. Plant Physiol. 131, 1191-1208. doi: 10.1104/pp.013052

Viotti, C., Bubeck, J., Stierhof, Y. D., Krebs, M., Langhans, M., Van Den Berg, W., et al. (2010). Endocytic and secretory traffic in Arabidopsis merge in the transGolgi network/early endosome, an independent and highly dynamic organelle. Plant Cell 22, 1344-1357. doi: 10.1105/tpc.109.072637

Voiniciuc, C., Pauly, M., and Usadel, B. (2018). Monitoring polysaccharide dynamics in the plant cell wall. Plant Physiol. 176, 2590-2600. doi: 10.1104/pp. 17.01776

Vukasinovic, N., and Zarsky, V. (2016). Tethering complexes in the arabidopsis endomembrane system. Front. Cell Dev. Biol. 4:46. doi: 10.3389/fcell.2016. 00046

Wallace, M. L., Anderson, S. J., Mazumdar, S., Kong, L., and Mulsant, B. H. (2012). Incorporating temporal features of repeatedly measured covariates into treestructured survival models. Biom. J. 54, 181-196. doi: 10.1002/bimj.201100013

Wang, B., Mcclosky, D. D., Anderson, C. T., and Chen, G. (2016). Synthesis of a suite of click-compatible sugar analogs for probing carbohydrate metabolism. Carbohydr. Res. 433, 54-62. doi: 10.1016/j.carres.2016.07.012

Wang, H., Zhuang, X., Wang, X., Law, A. H., Zhao, T., Du, S., et al. (2016). A distinct pathway for polar exocytosis in plant cell wall formation. Plant Physiol. 172, 1003-1018.

Wang, J., Ding, Y., Hillmer, S., Miao, Y., Lo, S. W., Wang, X., et al. (2010). EXPO, an exocyst-positive organelle distinct from multivesicular endosomes and autophagosomes, mediates cytosol to cell wall exocytosis in Arabidopsis and tobacco cells. Plant Cell 22, 4009-4030. doi: 10.1105/tpc.110.080697

Wang, P., Chen, X., Goldbeck, C., Chung, E., and Kang, B. H. (2017). A distinct class of vesicles derived from the trans-Golgi mediates secretion of xylogalacturonan in the root border cell. Plant J. 92, 596-610. doi: 10.1111/tpj. 13704

Wang, X., Chung, K. P., Lin, W., and Jiang, L. (2017). Protein secretion in plants: conventional and unconventional pathways and new techniques. J. Exp. Bot. 69, 21-37. doi: 10.1093/jxb/erx262

Wattelet-Boyer, V., Brocard, L., Jonsson, K., Esnay, N., Joubes, J., Domergue, F., et al. (2016). Enrichment of hydroxylated C24- and C26-acyl-chain sphingolipids mediates PIN2 apical sorting at trans-Golgi network subdomains. Nat. Commun. 7:12788. doi: 10.1038/ncomms 12788

Wong, M., and Munro, S. (2014). Membrane trafficking. The specificity of vesicle traffic to the Golgi is encoded in the golgin coiled-coil proteins. Science 346:1256898. doi: 10.1126/science. 1256898

Woollard, A. A., and Moore, I. (2008). The functions of Rab GTPases in plant membrane traffic. Curr. Opin. Plant Biol. 11, 610-619. doi: 10.1016/j.pbi.2008. 09.010

Worden, N., Park, E., and Drakakaki, G. (2012). Trans-Golgi network-an intersection of trafficking cell wall components(f). J. Integr. Plant Biol. 54, 875-886. doi: 10.1111/j.1744-7909.2012.01179.x

Worden, N., Wilkop, T. E., Esteve, V. E., Jeannotte, R., Lathe, R., Vernhettes, S., et al. (2015). CESA TRAFFICKING INHIBITOR inhibits cellulose deposition and interferes with the trafficking of cellulose synthase complexes and their associated proteins KORRIGAN1 and POM2/CELLULOSE SYNTHASE
INTERACTIVE PROTEIN1. Plant Physiol. 167, 381-393. doi: 10.1104/pp.114. 249003

Young, R. E., Mcfarlane, H. E., Hahn, M. G., Western, T. L., Haughn, G. W., and Samuels, A. L. (2008). Analysis of the Golgi apparatus in Arabidopsis seed coat cells during polarized secretion of pectin-rich mucilage. Plant Cell 20, 1623-1638. doi: 10.1105/tpc.108.058842

Yu, M., and Zhao, J. (2012). The cytological changes of tobacco zygote and proembryo cells induced by beta-glucosyl Yariv reagent suggest the involvement of arabinogalactan proteins in cell division and cell plate formation. BMC Plant Biol. 12:126. doi: 10.1186/1471-2229-12-126

Zeng, W., Ford, K. L., Bacic, A., and Heazlewood, J. L. (2018). N-linked Glycan Micro-heterogeneity in Glycoproteins of Arabidopsis. Mol. Cell. Proteomics 17, 413-421. doi: 10.1074/mcp.RA117.000165

Zhang, G. F., and Staehelin, L. A. (1992). Functional compartmentation of the golgi apparatus of plant cells : immunocytochemical analysis of high-pressure frozenand freeze-substituted sycamore maple suspension culture cells. Plant Physiol. 99, 1070-1083. doi: 10.1104/pp.99.3.1070

Zhang, J., Hill, D. R., and Sylvester, A. W. (2007). Diversification of the RAB guanosine triphosphatase family in dicots and monocots. J. Integr. Plant Biol. 49, 1129-1141. doi: 10.1111/j.1672-9072.2007.00520.x

Zhang, L., Zhang, H., Liu, P., Hao, H., Jin, J. B., and Lin, J. (2011). Arabidopsis R-SNARE proteins VAMP721 and VAMP722 are required for cell plate formation. PLoS One 6:e26129. doi: 10.1371/journal.pone.0026129

Zhen, Y., and Stenmark, H. (2015). Cellular functions of Rab GTPases at a glance. J. Cell Sci. 128, 3171-3176. doi: 10.1242/jcs.166074

Zheng, H., Bednarek, S. Y., Sanderfoot, A. A., Alonso, J., Ecker, J. R., and Raikhel, N. V. (2002). NPSN11 is a cell plate-associated SNARE protein that interacts with the syntaxin KNOLLE. Plant Physiol. 129, 530-539. doi: 10.1104/pp. 003970

Zheng, Y., Wang, X., Chen, Y., Wagner, E., and Cosgrove, D. J. (2018). Xyloglucan in the primary cell wall: assessment by FESEM, selective enzyme digestions and nanogold affinity tags. Plant J. 93, 211-226. doi: 10.1111/tpj. 13778

Zhu, C., Ganguly, A., Baskin, T. I., Mcclosky, D. D., Anderson, C. T., Foster, C., et al. (2015). The fragile Fiberl kinesin contributes to cortical microtubulemediated trafficking of cell wall components. Plant Physiol. 167, 780-792. doi: 10.1104/pp.114.251462

Zhu, X., Li, S., Pan, S., Xin, X., and Gu, Y. (2018). CSI1, PATROL1, and exocyst complex cooperate in delivery of cellulose synthase complexes to the plasma membrane. Proc. Natl. Acad. Sci. U.S.A. 115, E3578-E3587. doi: 10.1073/pnas. 1800182115

Zhu, Y., and Chen, X. (2017). Expanding the scope of metabolic glycan labeling in Arabidopsis thaliana. Chembiochem 18, 1286-1296. doi: 10.1002/cbic. 201700069

Zuo, J., Niu, Q. W., Nishizawa, N., Wu, Y., Kost, B., and Chua, N. H. (2000). KORRIGAN, an Arabidopsis endo-1,4-beta-glucanase, localizes to the cell plate by polarized targeting and is essential for cytokinesis. Plant Cell 12, 1137-1152. doi: $10.1105 /$ tpc.12.7.1137

Conflict of Interest Statement: The authors declare that the research was conducted in the absence of any commercial or financial relationships that could be construed as a potential conflict of interest.

Copyright (c) 2018 Sinclair, Rosquete and Drakakaki. This is an open-access article distributed under the terms of the Creative Commons Attribution License (CC BY). The use, distribution or reproduction in other forums is permitted, provided the original author(s) and the copyright owner(s) are credited and that the original publication in this journal is cited, in accordance with accepted academic practice. No use, distribution or reproduction is permitted which does not comply with these terms. 